\title{
Phenotypic and genotypic approaches for detection of anthelmintic resistant sheep gastrointestinal nematodes from Brazilian northeast
}

\author{
Abordagens fenotípica e genotípica para detecção de resistência anti- \\ helmíntica em nematoides gastrintestinais de ovinos no nordeste do Brasil \\ José Vilemar de Araújo-Filho'; Wesley Lyeverton Correia Ribeiro²; Weibson Paz Pinheiro André1; \\ Géssica Soares Cavalcante'; Jéssica Maria Leite dos Santos3; Jomar Patrício Monteiro 3,4; \\ Iara Tersia Freitas Macedo'; Lorena Mayana Beserra de Oliveira'; Claudia Maria Leal Bevilaqua1* ${ }^{10}$ \\ 'Laboratório de Doenças Parasitárias, Programa de Pós-graduação em Ciências Veterinárias, Faculdade de Veterinária, Universidade \\ Estadual do Ceará - UECE, Fortaleza, CE, Brasil \\ ${ }^{2}$ Departamento de Fisiologia e Farmacologia, Faculdade de Medicina, Universidade Federal do Ceará - UFC, Fortaleza, CE, Brasil \\ ${ }^{3}$ Centro Universitário INTA - UNINTA, Sobral, CE, Brasil \\ ${ }^{4}$ Embrapa Caprinos e Ovinos, Sobral, CE, Brasil
}

How to cite: Araújo-Filho JV, Ribeiro WLC, André WPP, Cavalcante GS, Santos JML, Monteiro JP, et al. Phenotypic and genotypic approaches for detection of anthelmintic resistant sheep gastrointestinal nematodes from Brazilian northeast. Braz J Vet Parasitol 2021; 30(2): e005021. https://doi.org/10.1590/S1984-29612021048

\begin{abstract}
The aim of this study was to characterize the anthelmintic resistance (AR) of a sheep gastrointestinal nematode population, named Caucaia, from northeastern Brazil. Phenotypic tests performed were: egg hatch (EHT), larval development (LDT) and fecal egg count reduction (FECRT). Benzimidazoles (BZs) genotypic evaluation was by frequency of single nucleotide polymorphisms (SNPs) F200Y, F167Y and E198A, and for levamisole (LEV), by frequency of resistance alleles of Hco-acr-8 gene. The primers were designed specifically for Haemonchus contortus. Effective concentrations 50\% (EC50) for BZs (EHT), and for macrocyclic lactones (MLS) and LEV (LDT) were $1.02 \mu \mathrm{g} / \mathrm{mL}, 1.81 \mathrm{ng} / \mathrm{mL}$ and $0.04 \mu \mathrm{g} / \mathrm{mL}$, respectively. Resistance ratios for MLs and LEV were 0.91 and 3.07, respectively. FECRT efficacies of BZs, MLs, monepantel (MPTL) and LEV were 52.4; 87.0; 94.5 and $99.6 \%$, respectively. qPCR for BZs demonstrated resistance allele frequencies of 0\%,26.24\% and $69.08 \%$ for SNPs E198A, F200Y and F167Y, respectively. For LEV, 54.37\% of resistance alleles were found. There was agreement between EHT, FECRT and qPCR for BZs, and agreement between LDT and qPCR for LEV. Thus, based on higher sensitivity of qPCR, and phenotypic evaluation, the Caucaia population was considered resistant to BZs, MLs, LEV and suspect for MPTL.
\end{abstract}

Keywords: Nematode, small ruminants, anthelmintic resistance, diagnosis, qPCR.

\section{Resumo}

O objetivo deste estudo foi caracterizar a resistência anti-helmíntica (RA) da população de nematoides gastrintestinais de ovinos, denominada Caucaia, do Nordeste brasileiro. Os testes fenotípicos foram: eclosão de ovos (TEO), desenvolvimento larvar (TDL) e redução da contagem de ovos nas fezes (TRCOF). A avaliação genotípica para benzimidazóis (BZs) foi por frequência de polimorfismos de nucleotídeo único (SNPs) F200Y, F167Y e E198A; e para levamisol (LEV), pela frequência alélica para resistência no gene Hco-acr-8. Os "primers" foram específicos para Haemonchus contortus. As concentrações efetivas 50\% (CE50) para BZs (TEO) e para lactonas macrocíclicas (LMs) e LEV (TDL) foram 1,02 $\mu \mathrm{g} / \mathrm{mL}, 1,81 \mathrm{ng} / \mathrm{mL}$ e $0,04 \mu \mathrm{g} / \mathrm{mL}$, respectivamente. Os fatores de resistência para LMs e LEV foram 0,91 e 3,07, respectivamente. As eficácias para BZs, LMs, monepantel (MPTL) e LEV no TRCOF foram 52,4; 87,0; 94,5 e 99,6\%, respectivamente. A qPCR para BZs demonstrou frequências de 0\%, 26,24\% e 69,08\% para SNPs E198A, F200Y e F167Y, respectivamente. Para LEV foram encontrados $54,37 \%$ de alelos resistentes. Houve 
concordância entre TEO, TRCOF e qPCR para BZs, e entre TDL e qPCR para LEV. Baseada na maior sensibilidade da qPCR e avaliação fenotípica, a população Caucaia foi considerada resistente a BZs, LMs, LEV e suspeita para MPTL.

Palavras-chave: Nematoide, pequenos ruminantes, resistência anti-helmíntica, diagnóstico, qPCR.

\section{Introduction}

The anthelmintic resistance (AR), defined by Prichard et al. (1980) as the increase in the frequency of anthelmintic tolerance in a nematode population, is currently one of the biggest concerns faced by sheep and goat farmers worldwide.

The AR is widespread, and the occurrence of resistance and even multidrug resistance has been reported for the main pharmacological groups of anthelmintics used for gastrointestinal nematode control, such as benzimidazoles (BZs), macrocyclic lactones (MLs) and imidazothiazoles (Lamb et al., 2017; Cazajous et al., 2018). Monepantel (MPTL), one of the most recently released anthelmintic on the market, already has reports of resistance (Van den Brom et al., 2015; Cintra et al., 2016).

Diagnosis of AR is essential and has been made using phenotypic techniques, such as the egg hatch test (EHT), larval development test (LDT) and fecal egg count reduction test (FECRT), and genotypic techniques based on polymerase chain reaction (PCR) described for BZs and, most recently, levamisole (LEV). However, each technique demonstrates advantages and disadvantages regarding accuracy, reproducibility, cost and time spent (Coles et al., 1992; 2006; Santos et al., 2019).

The resistance mechanism to BZs is the more elucidated so far, and its molecular based diagnosis in trichostrongylids relies on the detection of single nucleotide polymorphisms (SNPs) in the coding gene for $\beta$-tubulin isotype 1. Three SNPs were described, with the first one located at codon 200 (F200Y), the second at codon 167 (F167Y) and the third one at codon 198 (E198A) (Kwa et al., 1994; Silvestre \& Cabaret, 2002; Ghisi et al., 2007).

The Hco-acr-8 gene codifies the a subunit that is part of a LEV sensitive acetylcholine receptor. Barrère et al. (2014) demonstrated a $63 \mathrm{bp}$ deletion within the exon $3 \mathrm{~b}$ of the Hco-acr-8 gene of H. contortus isolates resistant to LEV, suggesting it as a molecular marker for detection of AR to LEV. Later, Santos et al. (2019) described a quantitative real-time PCR (qPCR) protocol to detect this 63 bp deletion.

The spread of AR also motivated the search for alternative control methods. However, the genetic diversity among the parasite populations may led to variation in drug efficacy assessment. Thus, the use of nematode isolates with known resistance patterns may minimize variation during the AR evaluation (Chan-Pérez et al., 2016; Gaínza et al., 2016).

The aim of this study was to characterize the AR of a sheep gastrointestinal nematode population, named Caucaia, from northeastern Brazil, emphasizing the comparison between phenotypic and genotypic techniques for AR assessment.

\section{Materials and Methods}

\section{Gastrointestinal nematode population}

This study was approved by the Ethics Committee of the Universidade Estadual do Ceará and registered under the number $9472634 / 2018$.

The gastrointestinal nematode under evaluation in this study was obtained from a farm located in the municipality of Caucaia, Ceará state, northeastern Brazil ( $3^{\circ} 42^{\prime} 53^{\prime \prime} \mathrm{S}, 38^{\circ} 45^{\prime} 30^{\prime \prime} \mathrm{W}$ ). Feces were collected from 74 sheep, approximately $50 \%$ of the herd, and used for identification of nematode genera and phenotypic and genotypic evaluation of AR.

The farm followed a semi-intensive production practice with no rotational grazing. Anthelmintics were given to the whole herd twice a year, once in the dry and once in the rainy season, and the drug dosage determined based on visual weight estimations. Oxfendazole and IVM were the anthelmintic molecules used for nematode control and rotation between them was done every two years.

The genus Haemonchus was considered the main sheep gastrointestinal nematode found on the farm, with 91\% prevalence of L3 recovered from pooled fecal cultures from the animals. Trichostrongylus spp. (8\%) and Oesophagostomum spp. (1\%) were also found on the property. 


\section{Phenotypic Assays}

\section{Egg Hatch Test (EHT)}

The EHT was performed according to Coles et al. (1992). Briefly, $250 \mu \mathrm{L}$ of an egg suspension was incubated at $27^{\circ} \mathrm{C}$ for $48 \mathrm{~h}$ with $250 \mu \mathrm{L}$ of thiabendazole (Sigma-Aldrich ${ }^{\circledR}$, product code T8904-100G, $\geq 99 \%$ ) solution at 0.05, 0.1, $0.2,0.4,0.8$ or $1.6 \mu \mathrm{g} / \mathrm{mL}$, solubilized with $3 \%$ dimethyl sulfoxide (DMSO). The 3\% DMSO solution was the negative control. Lugol ${ }^{\circledR}$ was added and eggs and first-stage larvae (L1) were counted. Eight replicates for each treatment were performed and the efficacy was determined using the formula: (number of eggs/number of eggs + number of L1) $\times 100$.

\section{Larval Development Test (LDT)}

The LDT was performed according to Chagas et al. (2016) with adaptations. Aliquots of $170 \mu \mathrm{L}$ of an egg suspension, approximately 100 eggs in $100 \mu \mathrm{L}$ of suspension, were added to a 24-well microplate with $80 \mu \mathrm{L}$ of nutritive medium (Escherichia coli, yeast extract and amphotericin-B) to a final volume of $250 \mu \mathrm{L} /$ well.

Dilutions of tetramisole hydrochloride (Sigma-Aldrich ${ }^{\circledR}$, product code T1512-10G) in 1\% DMSO solution at 0.03, $0.09,0.19,0.39,0.78,1.56$ or $3.12 \mu \mathrm{g} / \mathrm{mL}$, and dilutions of ivermectin (IVM) (Ivomec ${ }^{\circledR}$, Merial) in water at $0.02,0.09$, $0.39,1.56,3.12,6.25,12.5$ or $50 \mathrm{ng} / \mathrm{mL}$ were used. The plates were incubated at $27^{\circ} \mathrm{C}$ for $24 \mathrm{~h}$ to obtain $\mathrm{L} 1$, and then, $250 \mu \mathrm{L}$ of anthelmintic and negative controls (DMSO $1 \%$ and water) were added. Seven days after incubation at $27^{\circ} \mathrm{C}, \mathrm{L} 1$, second- (L2) and third-stage larvae (L3) were counted. Eight replicates for each treatment were performed and the efficacy was determined using the formula: [number of $L 1+L 2 /($ number of $L 1+L 2+L 3)] \times 100$.

\section{Fecal egg count reduction test (FECRT)}

Sixty sheep from 7 to 16 months old with an average weight of $22 \pm 3.7 \mathrm{~kg}$ and epg greater than 1,000 were selected and divided ( $\mathrm{n}=15$ ) into four similar groups based on the epg average: $\mathrm{G1}, 4 \mathrm{mg} / \mathrm{kg}$ albendazole (Farmazole ${ }^{\circledR}$, Labovet); G2, 200 mg/kg ivermectin (Ivomec ${ }^{\circledR}$, Merial); G3, 5 mg/kg levamisole (Ripercol ${ }^{\circledR}$, Fort Dodge); and G4, $2.5 \mathrm{mg} / \mathrm{kg}$ monepantel (Zolvi ${ }^{\circledR}$, Novartis). The treatments were administered orally in a single dose. Fecal samples were collected on days $0,7,14$ and 21 post treatment to estimate epg reduction. Larval culture of a pool of feces of each group was performed to identify the nematode genus. The identification of L3 was based on Ueno \& Gonçalves (1998).

The anthelmintic efficacies of albendazole, IVM, LEV and MPTL were interpreted by FECRT based on the arithmetic mean of epg of the group using the formula: epg reduction $(\%)=100 \times(1-[\mathrm{T} 2 / \mathrm{T} 1])$, where the arithmetic mean of epg was compared in the treated animals on days 0 (T1) and 7, 14 or 21 after (T2) deworming (Kochapakdee et al., 1995). Confidence intervals 95\% were estimated by bootstrapping 1000 times using BootStreat 1.0 software (Cabaret, 2014).

\section{Genotypic Assay}

\section{DNA Extraction}

Genomic DNA extraction was performed according to Santos et al. (2017). Briefly, 10,000 eggs, recovered from naturally infected sheep prior to anthelmintic treatment in the FECRT, were suspended in digestion buffer (0.2\% SDS, $50 \mathrm{mM}$ EDTA, $50 \mathrm{mM}$ Tris-HCl, $0.4 \mathrm{mg} / \mathrm{mL}$ proteinase $\mathrm{K}, 100 \mu \mathrm{g} / \mathrm{mL}$ RNase, $\mathrm{pH}$ 8.0) and disrupted by shaking with $1 \mathrm{~mm}$ zirconia/silica beads in a Mini-BeadBeater-16 (Biospec Products, Bartlesville, OK, USA). DNA was alcohol precipitated and further subjected to phenol: chloroform (1:1) purification prior to further alcohol precipitation. The final pellet was resuspended in TE buffer and stored at $-20^{\circ} \mathrm{C}$.

\section{Quantitative Real-Time PCR (qPCR)}

qPCR for BZs resistance detection was performed according to Santos et al. (2017). Specific primers for the H. contortus SNPs F200Y, F167Y and E198A for sensitive and resistant alleles were used.

qPCR for LEV resistance detection was performed according to Santos et al. (2019). The primers used were designed to identify the presence or absence of the 63 bp indel in Hco-acr-8 exon 3b. 
Both reactions contained $12.5 \mu \mathrm{L}$ of 2×Fast Start Universal SYBR Green Master Mix (Roche, West Sussex, UK), $0.3 \mathrm{pmol} / \mu \mathrm{L}$ each primer (forward and reverse), 25 (BZ) or $50 \mathrm{ng}$ (LEV) of DNA and nuclease-free water (SigmaAldrich) for a total volume of $25 \mu \mathrm{L}$. For a negative control, nuclease-free water was used instead of $H$. contortus DNA. All qPCR tests were performed in triplicate.

The threshold cycle (Ct) for qPCR reactions was determined by the software Realplex 2.2 (Eppendorf, Hamburg, Germany), and allele frequencies were estimated as previously described (Germer et al., 2000), with modifications considering the efficiencies and slopes of the reactions for each allele.

The frequency of resistant homozygous was calculated as the frequency of resistance allele multiplied by itself $\left(q^{2}\right)$. The frequency of heterozygous at both positions was calculated for SNPs F167Y and F200Y as follows: $2 \times p 167 \times q 167 \times 2 \times p 200 \times q 200$, where $p$ and $q$ are the frequency of susceptible and resistance alleles, respectively. The same formula was adapted for estimation of heterozygous for LEV resistance as: $2 \times p$ Acr- $8 \times q A c r-8$ (Barrère et al., 2013). The frequencies were calculated assuming a population in Hardy-Weinberg equilibrium.

\section{Anthelmintic resistance assessment}

The gastrointestinal nematode population was considered resistant in the EHT and FECRT based on the WAAVP recommendations (Coles et al., 1992). For the EHT, a discriminating dose of $0.1 \mu \mathrm{g} / \mathrm{mL}$ was suggested for thiabendazole. In the FECRT, AR was present if reduction in epg was less than 95\% and the lower limit of the 95\% confidence interval was below $90 \%$.

In the LDT, since there are no discriminating doses for IVM or LEV, AR was suggested by comparing the effective concentration to inhibit 50\% (EC50) for the evaluated nematode population with that for a well-known susceptible H. contortus isolate, Inbred-susceptible Edinburgh (ISE), since Haemonchus was the most representative genera found in the population (91\%). The resistance ratio (RR) was calculated by the formula RR = EC50 for the evaluated population/EC50 for the ISE isolate (Sangster \& Dobson, 2002). The ISE isolate previously demonstrated EC50 values of $1.974 \mathrm{ng} / \mathrm{mL}$ and $0.013 \mu \mathrm{g} / \mathrm{mL}$ for IVM and LEV, respectively (Santos et al., 2017; 2019).

QPCR analysis for BZ and LEV resistance used allele frequencies of the ISE isolate for comparison. In addition, data regarding allele frequencies of a multiresistant isolate, Kokstad, were also used to perform LEV evaluation (Santos et al., 2014; et al., 2019).

\section{Statistical analysis}

EHT and LDT results were analyzed by analysis of variance (ANOVA) using GraphPad Prism ${ }^{\circledR} 5.0$ software. Oneway ANOVA followed by Tukey's test was used to compare data regarding the same treatment. The results were expressed as the mean efficacy percentage of egg hatching and larval development \pm the standard deviation and processed to generate a dose-response curve. The EC50 of anthelmintics on egg hatching and larval development was determined by probit regression using the SPSS 22.0 program.

The data relative to FECRT were transformed onto $\log 10(x+1)$. Significant differences between the group means were determined by Tukey's test. The results were expressed as mean epg \pm standard deviation. The significance level of $5 \%$ was adopted for all analysis.

\section{Results}

\section{Phenotypic Assays}

In the EHT, the highest dose of thiabendazole $(1.6 \mu \mathrm{g} / \mathrm{mL})$ inhibited $67.53 \%( \pm 7.45 \%)$ of egg hatching, with an EC50 value of $1.02 \mu \mathrm{g} / \mathrm{mL}$. Therefore, since the EC50 value was ten times higher than the discriminating dose $(0.1 \mu \mathrm{g} / \mathrm{mL})$, the Caucaia population was considered resistant to BZs.

Larval development test dose-response curves are shown in Figure 1. In the LDT, larval development inhibition for IVM ranged from $6.96 \%( \pm 5.74 \%)$ to $100 \%(0.02-50 \mathrm{ng} / \mathrm{mL})$ (Figure $1 \mathrm{~A})$. The efficacy for LEV ranged from $39.17 \%$ $( \pm 5.56 \%)$ to $100 \%(0.03-3.12 \mu \mathrm{g} / \mathrm{mL})$ (Figure 1B). The EC50 values and RR for IVM and LEV were $1.81 \mathrm{ng} / \mathrm{mL}(\mathrm{RR}=0.91)$ and $0.04 \mu \mathrm{g} / \mathrm{mL}$ ( $R R=3.07$ ), respectively. Based on the comparison to the EC50 values for the $H$. contortus ISE isolate, the EC50 values for the evaluated isolate demonstrated susceptibility to IVM and a low resistance pattern for LEV. 

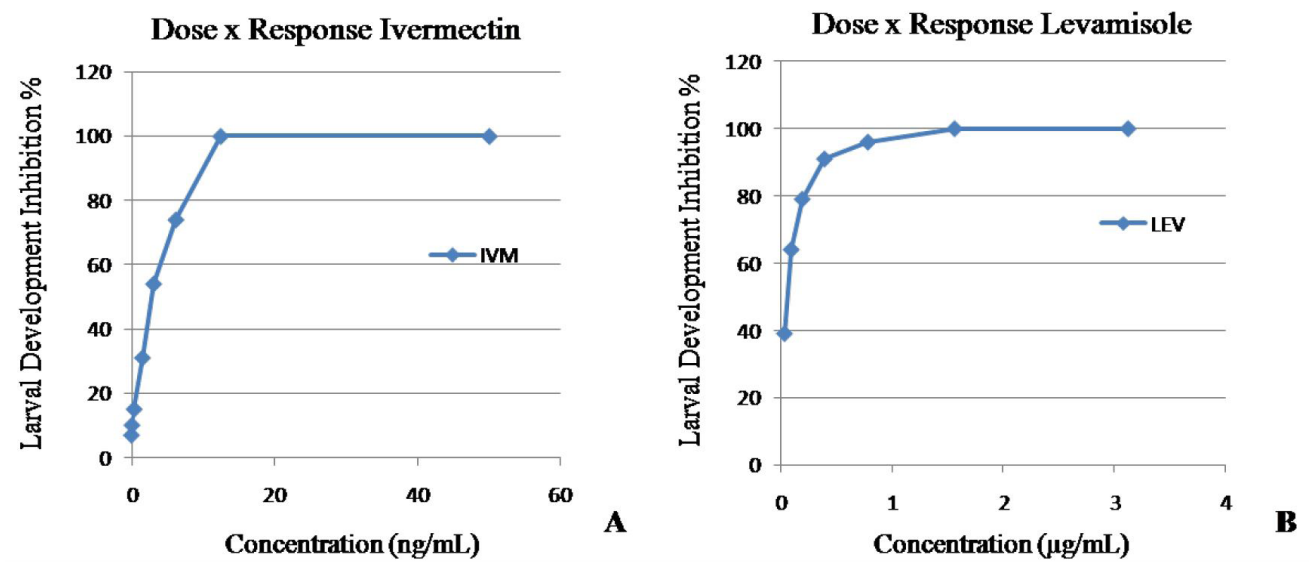

Figure 1. Larval development test dose-response curves of ivermectin (A) and levamisole (B) against sheep gastrointestinal nematodes of the Caucaia population.

The FECRT results are presented in Table 1. Only LEV met the WAAVP recommendations to be considered an effective anthelmintic, with epg reduction and highest efficacy of $99.6 \%$. The second most effective anthelmintic was MPTL, with efficacy ranging from $92.7-94.5 \%$. The highest efficacies of albendazole and IVM were $52.4 \%$ and $87.0 \%$, respectively. Data regarding the main results in the phenotypic tests are summarized in Table 2.

The larvae recovered from fecal cultures were identified and the results are shown in Table 3. The nematodes $\mathrm{H}$. contortus, Trichostrongylus spp and Oesophagostomum spp were found, and among them, $\mathrm{H}$. contortus was predominant throughout the test with percentage ranging from 73.58-94.0\%. The highest percentage for Trichostrongylus spp and Oesophagostomum spp were 21.79 and $18.0 \%$, respectively.

\section{Genotypic Assay}

qPCR results are shown in Table 4 and demonstrated resistance allele frequencies of 0, 26.24 and $69.08 \%$ for the SNPs E198A, F200Y and F167Y, respectively. For LEV, the frequency of the resistance allele found in the Caucaia nematode population for $\mathrm{H}$. contortus was $54.37 \%$, compared to $38.5 \%$ found in the ISE isolate. Therefore, the H. contortus in the Caucaia population had a higher frequency of resistance alleles than the ISE isolate, which was susceptible to all classes of anthelmintic drugs.

Table 1. Eggs per gram of feces (mean epg \pm standard deviation), efficacy (\%) and 95\% confidence intervals (Cls) for albendazole, ivermectin, levamisole and monepantel in the fecal egg count reduction test (FECRT).

\begin{tabular}{|c|c|c|c|c|}
\hline Anthelmintics & Day 0 & Day 7 & Day 14 & Day 21 \\
\hline \multicolumn{5}{|l|}{ Albendazole } \\
\hline Mean epg & $2,246 \pm 1,928^{a}$ & $1,067 \pm 1,682^{b}$ & $2,317 \pm 3,756^{a}$ & $1,600 \pm 2,287^{a}$ \\
\hline Efficacy (CI) & - & $52.4(-15-86)$ & 0 & $28.7(-59-80)$ \\
\hline \multicolumn{5}{|l|}{ Ivermectin } \\
\hline Mean epg & $1,993 \pm 1,510^{a}$ & $786 \pm 1,030^{b}$ & $276 \pm 281^{b}$ & $523 \pm 645^{b}$ \\
\hline Efficacy (Cl) & - & $61.8(11-87)$ & $87.0(73-96)$ & 72.5 (42-91) \\
\hline \multicolumn{5}{|l|}{ Levamisole } \\
\hline Mean epg & $2,107 \pm 1,959^{a}$ & $7 \pm 18^{b}$ & $64 \pm 123^{b}$ & $46 \pm 90^{b}$ \\
\hline Efficacy (Cl) & - & $99.6(99-101)$ & $96.9(92-100)$ & $97.7(94-101)$ \\
\hline \multicolumn{5}{|l|}{ Monepantel } \\
\hline Mean epg & $1,988 \pm 1,389^{a}$ & $143 \pm 202^{b}$ & $106 \pm 156^{b}$ & $103 \pm 143^{b}$ \\
\hline Efficacy (Cl) & - & $92.7(82-100)$ & $94.5(86-100)$ & 93.0 (85-99) \\
\hline
\end{tabular}

Small letters compare means in the rows. Different letters indicate significantly different values $(p<0.05)$. 
Table 2. Efficacy of anthelmintic drugs in the egg hatch test (EHT), larval development test (LDT) and fecal egg count reduction test (FECRT), and the resistance ratios (RRs) for ivermectin and levamisole in the LDT.

\begin{tabular}{cccccc}
\hline Assay & Drug & EC50/Efficacy (E) Caucaia & EC50 ISE $\boldsymbol{H}$. contortus isolate & Resistance Ratio (RR) \\
\hline EHT & Thiabendazole & $\mathrm{EC50}=1.02 \mu \mathrm{g} / \mathrm{mL}(0.58-3.24)^{\mathrm{b}}$ & & - \\
LDT & Ivermectin & $\mathrm{EC50}=1.81 \mathrm{ng} / \mathrm{mL}(0.35-5.62)^{\mathrm{b}}$ & $\mathrm{EC50}=1.974 \mathrm{ng} / \mathrm{mL}(1.37-2.67)^{\mathrm{b}}$ & 0.91 \\
& Levamisole & $\mathrm{EC50}=0.04 \mu \mathrm{g} / \mathrm{mL}(0.035-0.057)^{\mathrm{b}}$ & $\mathrm{EC50}=0.013 \mu \mathrm{g} / \mathrm{mL}(0.009-0.018)^{\mathrm{b}}$ & - & - \\
FECRT & Albendazole & $\mathrm{E}=52.4 \%(-15-86)^{\mathrm{b}}$ & & - \\
& Ivermectin & $\mathrm{E}=87.0 \%(73-96)^{\mathrm{b}}$ & & - \\
& Levamisole & $\mathrm{E}=99.6 \%(99-101)^{\mathrm{b}}$ & & - \\
& Monepantel & $\mathrm{E}=94.5 \%(86-100)^{\mathrm{b}}$ & & - \\
\hline
\end{tabular}

abtained by comparison with the sensitive isolate ISE; b95\% confidence interval.

Table 3. Infective larvae (L3) count and percentage of nematode genera recovered from larval cultures of sheep on days 7,14 and 21 post-treatment with albendazole (ABZ), ivermectin (IVM), levamisole (LEV) or monepantel (MPTL).

\begin{tabular}{|c|c|c|c|c|c|c|c|}
\hline \multirow{2}{*}{ Treatment } & \multicolumn{2}{|c|}{ H. contortus } & \multicolumn{2}{|c|}{ Trichostrongylus spp. } & \multicolumn{2}{|c|}{ Oesophagostomum spp. } & \multirow{2}{*}{ Total } \\
\hline & Larvae (n) & $\%$ & Larvae (n) & $\%$ & Larvae (n) & $\%$ & \\
\hline No treatment & 91 & 91.0 & 8 & 8.0 & 1 & 1.0 & 100 \\
\hline$A B Z-D 7$ & 88 & 88.0 & 10 & 10.0 & 2 & 2.0 & 100 \\
\hline$A B Z-D 14$ & 94 & 94.0 & 6 & 6.0 & 0 & 0.0 & 100 \\
\hline$A B Z-D 21$ & 92 & 92.0 & 7 & 7.0 & 1 & 1.0 & 100 \\
\hline IVM - D7 & 89 & 89.0 & 9 & 9.0 & 2 & 2.0 & 100 \\
\hline IVM - D14 & 83 & 83.0 & 16 & 16.0 & 1 & 1.0 & 100 \\
\hline IVM - D21 & 88 & 88.0 & 12 & 12.0 & 0 & 0.0 & 100 \\
\hline LEV - D7 & 39 & 73.58 & 11 & 20.75 & 3 & 5.66 & $53^{a}$ \\
\hline LEV - D14 & 61 & 78.20 & 17 & 21.79 & 0 & 0.0 & $78^{\mathrm{a}}$ \\
\hline LEV - D21 & 82 & 82.0 & 16 & 16.0 & 2 & 2.0 & 100 \\
\hline MPTL - D7 & 82 & 82.0 & 7 & 7.0 & 11 & 11.0 & 100 \\
\hline MPTL - D14 & 79 & 79.0 & 7 & 7.0 & 14 & 14.0 & 100 \\
\hline MPTL - D21 & 77 & 77.0 & 5 & 5.0 & 18 & 18.0 & 100 \\
\hline
\end{tabular}

alt was not possible to recover $100 \mathrm{~L} 3$ from the LEV group on days 7 and 14 post-treatment. Therefore, all recovered L3 were identified.

Table 4. Quantitative PCR mean Cts, standard deviations and resistance allele frequencies for the SNPs F200Y, F167Y and E198A and for the Hco-acr-8 gene in Haemonchus contortus.

\begin{tabular}{|c|c|c|c|c|c|c|c|c|}
\hline \multirow{3}{*}{ qPCR target } & \multirow{2}{*}{\multicolumn{2}{|c|}{$\begin{array}{l}\text { H. contortus - Caucaia } \\
\mathrm{Ct}^{\mathrm{a}} \pm \mathrm{SD} \text { of each allele }\end{array}$}} & \multirow{3}{*}{$\begin{array}{c}\text { Resistance } \\
\text { allele (\%) }\end{array}$} & \multirow{3}{*}{$\begin{array}{c}\text { Resistant } \\
\text { homozygous } \\
(\%)\end{array}$} & \multirow{3}{*}{$\begin{array}{c}\text { Proportion } \\
\text { heterozygous } \\
\text { at both } \\
\text { positions (\%) }\end{array}$} & ISE IS & olate & \multirow{3}{*}{$\begin{array}{r}\text { Resistance } \\
\text { allele (\%) }\end{array}$} \\
\hline & & & & & & \multicolumn{2}{|c|}{$\mathrm{Ct}^{\mathrm{a}} \pm \mathrm{SD}$ of each allele } & \\
\hline & Sensitive & Resistant & & & & Sensitive & Resistant & \\
\hline SNP - F200Y & $30.82 \pm 0.63$ & $32.31 \pm 0.87$ & 26.24 & 6.88 & 16.53 & $24.33 \pm 0.49$ & $30.13 \pm 0.24$ & 1.76 \\
\hline SNP - F167Y & $29.36 \pm 0.10$ & $28.20 \pm 0.70$ & 69.08 & 47.72 & & $26.02 \pm 0.38$ & - & - \\
\hline SNP - E198A & $29.36 \pm 0.10$ & - & - & - & - & $23.80 \pm 0.04$ & - & - \\
\hline Hco-acr-8 & $29.20 \pm 0.13$ & $28.94 \pm 0.42$ & 54.37 & 29.56 & 49.61 & $24.63 \pm 0.12$ & $24.37 \pm 0.19$ & 38.5 \\
\hline
\end{tabular}

aMean threshold cycle (Ct) of three replicates and the standard deviation (SD). 


\section{Discussion}

In this study, in vitro (EHT and LDT) and in vivo (FECRT) phenotypic and genotypic (qPCR) assays were performed and compared to characterize the AR of a sheep gastrointestinal nematode population. The Caucaia population was considered resistant to BZs in all the tests performed, both genotypic and phenotypic. On the other hand, the resistance profile for MLs and imidazothiazoles differed between the LDT and FECRT.

The occurrence of resistance to BZs has been reported for a long time, being found widespread throughout the state of Ceará, northeastern Brazil, and perhaps the agreement between the tests may be based on the advanced level of resistance found, as demonstrated by $52.4 \%$ and $0 \%$ efficacy in epg reduction on day 7 and 14 post treatment (Vieira et al., 1989; Melo et al., 2009).

The predominance of the SNP F167Y (69.08\%), with the second highest percentage for F200Y (26.24\%), and the absence of E198A codon polymorphism corroborate the findings of Santos et al. (2017), who evaluated the pattern of BZs resistance of $H$. contortus from 20 sheep farms in Ceará state. Lambert et al. (2017) also indicated more relevance for SNP F167Y in semi-arid regions of the state of Bahia, with 32.7\% of resistant homozygous larvae compared to SNP F200Y (18.9\%). However, the opposite has been reported in many other studies, with higher allelic frequencies for SNP F200Y in H. contortus populations from Uruguay (Munguía et al., 2018), from Italy and Switzerland (Ramunke et al., 2016) and from France (Silvestre \& Cabaret, 2002).

The results obtained via RR analysis of the LDT did not correspond to the findings from the FECRTs for IVM and LEV. IVM was considered effective in the LDT but did not achieve the efficacy recommended by the WAAVP in the FECRT since the IVM efficacy was below $95 \%(87 \%)$ and the lower confidence interval below $90 \%$ (73\%). Kotze et al. (2002) also observed disagreement between FECRT and LDT results when evaluating the EC50 of IVPro H. contortus isolate, showing a different pattern of resistance between free-living and parasitic life stages, as demonstrated by a low level of IVM resistance in the LDT (RR=2.0-2.7) and almost no efficacy in the FECRT (4\%). However, IVM resistance was more distinguishable from the susceptible isolate (McMaster) when using the EC99, with RR values of 3.9 and 10.5 for IVM monosaccharide and aglycone, respectively. Chagas et al. (2016) also demonstrated a better correlation between in vitro (LDT) and in vivo (FECRT) results for LEV, especially, for an isolate with higher level of resistance (Embrapa2014), with 70.4\% of egg count reduction (FECRT) and RR of 4.20 and 11, when using EC50 and EC90, respectively. The Embrapa2010 isolate, on the other hand, showed in comparison to McMaster, 91.1\% of efficiency (FECRT) and RR of 1.57 (EC50) and 1.60 (EC90) in the LDT.

In the FECRT, the Caucaia nematode population was considered susceptible to LEV, with an efficacy of $99.6 \%$. However, in the LDT, the RR was 3.07, demonstrating that, although at a low level, taking into account a cut-off of 3 , resistance was present, but not necessarily expressed phenotypically in FECRT, since its results are more reliable when resistance is already present in more than $25 \%$ of the parasite population (Coles et al., 1992; Dolinská et al., 2013). However, FECRT remains one of the most performed tests for anthelmintic efficacy evaluation, and as reported by Levecke et al. (2018), even with the need for a combination of uncertainty interval methodologies (confidence and credible intervals) for an improved interpretation, the criteria currently used to classify the efficacy of anthelmintic drugs are the most appropriate (Martin et al., 1989; Coles et al., 2006).

The same $H$. contortus isolate can be classified as sensitive in one test and resistant in another. George et al. (2018) reported a low RR (up to 2) when evaluating avermectin/milbemycin compounds in an L3 motility test and a larvae migration inhibition assay. However, when evaluated in the LDT, much higher RR values were obtained (at least 16.48). This discrepancy in drug efficacy between life stages may be attributed to multiple factors linked directly to the parasite, for example, the expression of drug targets in larvae/adults and parasite mechanisms of drug detoxification and drug efflux, such as ATP-binding cassette (ABC) transporters. In addition, for the in vivo assay, equally complex factors linked to the host are also present, such as the immune response and pharmacokinetic profile, which makes diagnosing resistance even more challenging (Gill et al., 1995; George et al., 2018; Lanusse et al., 2018).

Although Santos et al. (2019) have demonstrated success in the detection of a 63 bp deletion in the H. contortus Hco-acr- 8 gene by qPCR, and although this technique presents high sensitivity for detection of resistance alleles, the deletion of $63 \mathrm{bp}$ does not necessarily indicate the phenotypic expression of LEV resistance for all $H$. contortus isolates. In fact, the deletion has already been described in LEV susceptible isolates, such as, the McMaster and the ZAIRE-5 (Barrère et al., 2014; Chagas et al., 2016). Besides Hco-acr-8, other genes coding for subunits of the LEV sensitive receptor (Hco-unc-63a, Hco-unc-63b and Hco-unc-29) or coding for ancillary proteins, involved in the assembly and functioning of the receptors (Hco-unc-74, Hco-unc-50, Hco-ric-3.1 and Hco-ric-3.2), could play a role in the development of LEV resistance in some isolates, suggesting a polygenic resistance mechanism, which makes its detection by targeting just one molecular marker a very difficult task (Neveu et al., 2010; Sarai et al., 2013; 2014). 
Given the genetic diversity present in $H$. contortus, even isolates that share sensitive phenotypes may have different EC50 values, and therefore, the use of only one isolate as a sensitive standard may not be the most suitable for the LDT (Rezansoff et al., 2019). qPCR demonstrated that the $H$. contortus in the Caucaia population had $54.37 \%$ resistance alleles for the Hco-acr-8 gene. The ISE isolate showed a high percentage of LEV resistance alleles (38.5\%), which could indicate that may be individuals in this population who have characteristics associated with LEV resistance. Therefore, since it may impact the RR calculation, the best option would be to use other $H$. contortus susceptible isolates to make the evaluation based on the RR more reliable. Though comparing the qPCR and FECRT, 54.37\% resistance alleles did not promote a significant impact on LEV efficacy. However, when evaluating a multidrug-resistant $H$. contortus isolate (Kokstad), Santos et al. (2019) observed $100 \%$ resistance alleles for Hco-acr-8. Thus, it seems that LEV efficacy in FECRT is overestimated, which is plausible due to the imprecise nature of epg count and lack of sensitivity compared to that of qPCR (Levecke et al., 2012).

The efficacy of MPTL in the FECRT was below 95\% (94.5\%), and the lower confidence interval was below 90\% (86\%). Considering that the efficacy and confidence intervals were very close to the limits recommended by WAAVP and since epg may show high variation, it is not possible to affirm MPTL resistance. Therefore, the Caucaia nematode population was considered suspect of being resistant (Coles et al., 1992). Reports of resistance to MPTL have become more frequent, with data usually obtained after performing the FECRT. It has been shown that $H$. contortus is capable of developing resistance in a short period after use, even under target selective treatment conditions (Van den Brom et al., 2015; Sales \& Love, 2016; Albuquerque et al., 2017).

Studies focusing on molecular markers for diagnosing MPTL resistance are advancing. Mutations in the Hco-mptl-1 gene were found in resistant $H$. contortus, mainly in the retention of intron 15 (Bagnall et al., 2017). However, a suitable method for resistance detection still needs to be validated. Therefore, as occurred for IVM, we decided to evaluate MPTL efficacy only by phenotypic tests, in its case, the FECRT.

Although the nematode population was not exclusively composed by $H$. contortus, it was the main nematode present in that population, at a level of $91 \%$. There may be some influence of the Trichostrongylus (8\%) and the Oesophagostomum (1\%) found, at least in the phenotypic assessment. Therefore, the use of a pure nematode isolate in subsequent studies would be more suitable. On the other hand, for the genotypic evaluation by qPCR, the designed primers were specific for $\mathrm{H}$. contortus, and therefore, the influence of the other nematode genera would be unlikely.

\section{Conclusion}

The best correlation between phenotypic and genotypic test results was observed when testing for BZs, with agreement between the EHT, FECRT and qPCR, probably due to the high level of resistance in the Caucaia population. The RR value as a resistance parameter is reliable only when the standard isolate is truly sensitive to anthelmintics. Although QPCR is a very sensitive technique, a molecular marker for the detection of LEV resistance, ideal for all $H$. contortus isolates, is still unknown. Therefore, qPCR should be performed in association with phenotypic tests for a more reliable LEV resistance assessment. Thus, based on the phenotypic and genotypic valuation, the Caucaia population from Ceará state, Brazil was considered resistant to BZs, MLs, LEV and suspect for MPTL.

\section{Acknowledgements}

The authors would like to thank Conselho Nacional de Desenvolvimento Científico e Tecnológico (CNPq) for their financial support (142165/2018-2). Mr. Araújo-Filho has received a doctoral research scholarship and Dr. Bevilaqua has a research fellowship (305911/2019-8) from CNPq. We thank Embrapa Caprinos e Ovinos for infrastructure support.

\section{References}

Albuquerque ACA, Bassetto CC, Almeida FA, Amarante AF. Development of Haemonchus contortus resistance in sheep under suppressive or targeted selective treatment with monepantel. Vet Parasitol 2017; 246: 112-117. http://dx.doi.org/10.1016/j. vetpar.2017.09.010. PMid:28969773.

Bagnall NH, Ruffell A, Raza A, Elliott TP, Lamb J, Hunt PW, et al. Mutations in the Hco-mptl-1 gene in a field-derived monepantelresistant isolate of Haemonchus contortus. Int J Parasitol Drugs Drug Resist 2017; 7(2): 236-240. http://dx.doi.org/10.1016/j. ijpddr.2017.05.001. PMid:28501715. 
Barrère V, Beech RN, Charvet CL, Prichard RK. Novel assay for the detection and monitoring of levamisole resistance in Haemonchus contortus. Int J Parasitol 2014; 44(3-4): 235-241. http://dx.doi.org/10.1016/j.ijpara.2013.12.004. PMid:24503202.

Barrère V, Keller K, von Samson-Himmelstjerna G, Prichard RK. Efficiency of a genetic test to detect benzimidazole resistant Haemonchus contortus nematodes in sheep farms in Quebec, Canada. Parasitol Int 2013; 62(5): 464-470. http://dx.doi.org/10.1016/j. parint.2013.06.001. PMid:23773905.

Cabaret J. Reliable phenotypic evaluations of anthelminthic resistance in herbivores: how and when should they be done? In: Quick W, editor. Anthelmintics: Clinical Pharmacology, uses in veterinary medicine and efficacy. New York: Nova Science; 2014. p. 1-26.

Cazajous T, Prevot F, Kerbiriou A, Milhes M, Grisez C, Tropee A, et al. Multiple-resistance to ivermectin and benzimidazole of Haemonchus contortus population in a sheep flock from mainland France, first report. Vet Parasitol Reg Stud Reports 2018; 14: 103-105. http://dx.doi.org/10.1016/j.vprsr.2018.09.005. PMid:31014712.

Chagas ACS, Domingues LF, Gaínza YA, Barioni-Júnior W, Esteves SN, Niciura SCM. Target selected treatment with levamisole to control the development of anthelmintic resistance in a sheep flock. Parasitol Res 2016; 115(3): 1131-1139. http://dx.doi. org/10.1007/s00436-015-4844-x. PMid:26614360.

Chan-Pérez JI, Torres-Acosta JFJ, Sandoval-Castro CA, Hoste H, Castaneda-Ramírez GS, Vilarem G, et al. In vitro susceptibility of ten Haemonchus contortus isolates from different geographical origins towards acetone: water extracts of two tannin rich plants. Vet Parasitol 2016; 217: 53-60. http://dx.doi.org/10.1016/j.vetpar.2015.11.001. PMid:26827861.

Cintra MCR, Teixeira VN, Nascimento LV, Sotomaior CS. Lack of efficacy of monepantel against Trichostrongylus colubriformis in sheep in Brazil. Vet Parasitol 2016; 216: 4-6. http://dx.doi.org/10.1016/j.vetpar.2015.11.013. PMid:26801587.

Coles GC, Bauer C, Borgsteede FHM, Geerts S, Klei TR, Taylor MA, et al. World Association for the Advancement of Veterinary Parasitology (W.A.A.V.P.) methods for detection of anthelmintic resistance in nematodes of veterinary importance. Vet Parasitol 1992; 44(1-2): 35-44. http://dx.doi.org/10.1016/0304-4017(92)90141-U. PMid:1441190.

Coles GC, Jackson F, Pomroy WE, Prichard RK, Von Samson-Himmelstjerna G, Silvestre A, et al. The detection of anthelmintic resistance in nematodes of veterinary importance. Vet Parasitol 2006; 136(3-4): 167-185. http://dx.doi.org/10.1016/j. vetpar.2005.11.019. PMid:16427201.

Dolinská M, Königová A, Letková V, Molnár L, Várady M. Detection of ivermectin resistance by a larval development test-back to the past or a step forward? Vet Parasito/ 2013; 198(1-2): 154-158. http://dx.doi.org/10.1016/j.vetpar.2013.07.043. PMid:23993637.

Gaínza YA, Fantatto RR, Chaves FCM, Bizzo HR, Esteves SN, Chagas ACS. Piper aduncum against Haemonchus contortus isolates: cross resistance and the research of natural bioactive compounds. Rev Bras Parasitol Vet 2016; 25(4): 383-393. http://dx.doi. org/10.1590/s1984-29612016073. PMid:27925067.

George MM, Lopez-Soberal L, Storey BE, Howell SB, Kaplan RM. Motility in the L3 stage is a poor phenotype for detecting and measuring resistance to avermectin/milbemycin drugs in gastrointestinal nematodes of livestock. Int J Parasitol Drugs Drug Resist 2018; 8(1): 22-30. http://dx.doi.org/10.1016/j.ijpddr.2017.12.002. PMid:29274827.

Germer S, Holland MJ, Higuchi R. High-throughput SNP allele-frequency determination in pooled DNA samples by kinetic PCR. Genome Res 2000; 10(2): 258-266. http://dx.doi.org/10.1101/gr.10.2.258. PMid:10673283.

Ghisi M, Kaminsky R, Mäser P. Phenotyping and genotyping of Haemonchus contortus isolates reveals a new putative candidate mutation for benzimidazole resistance in nematodes. Vet Parasitol 2007; 144(3-4): 313-320. http://dx.doi.org/10.1016/j. vetpar.2006.10.003. PMid:17101226.

Gill JH, Redwin JM, Van WykJA, Lacey E. Avermectin inhibition of larval development in Haemonchus contortus - effects of ivermectin resistance. Int J Parasitol 1995; 25(4): 463-470. http://dx.doi.org/10.1016/0020-7519(94)00087-5. PMid:7635622.

Kochapakdee S, Pandey VS, Pralomkarn W, Choldumrongkul S, Ngampongsai W, Lawpetchara A. Anthelmintic resistance in goats in southern Thailand. Vet Rec 1995; 137(5): 124-125. http://dx.doi.org/10.1136/vr.137.5.124. PMid:8533258.

Kotze AC, Dobson RJ, Tyrrell KL, Stein PA. High-level ivermectin resistance in a field isolate of Haemonchus contortus associated with a low level of resistance in the larval stage: implications for resistance detection. Vet Parasitol 2002; 108(3): 255-263. http:// dx.doi.org/10.1016/S0304-4017(02)00200-5. PMid:12237144.

Kwa MSG, Veenstra JG, Roos MH. Benzimidazole resistance in Haemonchus contortus is correlated with a conserved mutation at amino acid 200 in $\beta$-tubulin isotype 1. Mol Biochem Parasitol 1994; 63(2): 299-303. http://dx.doi.org/10.1016/0166-6851(94)900663. PMid:7911975.

Lamb J, Elliott T, Chambers M, Chick B. Broad spectrum anthelmintic resistance of Haemonchus contortus in Northern NSW of Australia. Vet Parasito/ 2017; 241: 48-51. http://dx.doi.org/10.1016/j.vetpar.2017.05.008. PMid:28579030.

Lambert SM, Nishi SM, Mendonça LR, Souza BMPS, Julião FS, Gusmão PS, et al. Genotypic profile of benzimidazole resistance associated with SNP F167Y and F200Y beta-tubulin gene in Brazilian populations of Haemonchus contortus of goats. Vet Parasitol Reg Stud Rep 2017; 8: 28-34. http://dx.doi.org/10.1016/j.vprsr.2017.01.006. PMid:31014633.

Lanusse C, Canton C, Virkel G, Alvarez L, Costa-Junior L, Lifschitz A. Strategies to Optimize the Efficacy of Anthelmintic Drugs in Ruminants. Trends Parasito/ 2018; 34(8): 664-682. http://dx.doi.org/10.1016/j.pt.2018.05.005. PMid:29960843. 
Levecke B, Dobson RJ, Speybroeck N, Vercruysse J, Charlier J. Novel insights in the faecal egg count reduction test for monitoring drug efficacy against gastrointestinal nematodes of veterinary importance. Vet Parasitol 2012; 188(3-4): 391-396. http://dx.doi. org/10.1016/j.vetpar.2012.03.020. PMid:22521979.

Levecke B, Kaplan RM, Thamsborg SM, Torgerson PR, Vercruysse J, Dobson RJ. How to improve the standardization and the diagnostic performance of the fecal egg count reduction test? Vet Parasitol 2018; 253: 71-78. http://dx.doi.org/10.1016/j. vetpar.2018.02.004. PMid:29605007.

Martin PJ, Anderson N, Jarrett RG. Detecting benzimidazole resistance with faecal egg count reduction tests and in vitro assays. Aust Vet J 1989; 66(8): 236-240. http://dx.doi.org/10.1111/j.1751-0813.1989.tb13578.x. PMid:2590136.

Melo ACFL, Bevilaqua CML, Reis IF. Resistência aos anti-helmínticos benzimidazóis em nematóides gastrintestinais de pequenos ruminantes do semiárido nordestino brasileiro. Cienc Anim Bras 2009; 10(1): 294-300.

Munguía B, Teixeira R, Veroli MV, Marín M, Domínguez L. Molecular analysis of benzimidazole-resistance associated SNPs in Haemonchus contortus populations of Uruguay. Vet Parasitol Reg Stud Rep 2018; 13: 110-114. http://dx.doi.org/10.1016/j. vprsr.2018.05.001. PMid:31014856.

Neveu C, Charvet CL, Fauvin A, Cortet J, Beech RN, Cabaret J. Genetic diversity of levamisole receptor subunits in parasitic nematode species and abbreviated transcripts associated with resistance. Pharmacogenet Genomics 2010; 20(7): 414-425. http:// dx.doi.org/10.1097/FPC.0b013e328338ac8c. PMid:20531256.

Prichard RK, Hall CA, Kelly JD, Martin IC, Donald AD. The problem of anthelmintic resistance in nematodes. Aust Vet J 1980; 56(5): 239-250. http://dx.doi.org/10.1111/j.1751-0813.1980.tb15983.x. PMid:7002142.

Ramünke S, Melville L, Rinaldi L, Hertzberg H, de Waal T, von Samson-Himmelstjerna G, et al. Benzimidazole resistance survey for Haemonchus, Teladorsagia and Trichostrongylus in three European countries using pyrosequencing including the development of new assays for Trichostrongylus. Int J Parasitol Drugs Drug Resist 2016; 6(3): 230-240. http://dx.doi.org/10.1016/j.ijpddr.2016.10.002. PMid:27821282.

Rezansoff AM, Laing R, Martinelli A, Stasiuk S, Redman E, Bartley D, et al. The confounding effects of high genetic diversity on the determination and interpretation of differential gene expression analysis in the parasitic nematode Haemonchus contortus. Int J Parasitol 2019; 49(11): 847-858. http://dx.doi.org/10.1016/j.ijpara.2019.05.012. PMid:31525371.

Sales N, Love S. Resistance of Haemonchus sp. to monepantel and reduced efficacy of a derquantel / abamectin combination confirmed in sheep in NSW, Australia. Vet Parasitol 2016; 228: 193-196. http://dx.doi.org/10.1016/j.vetpar.2016.08.016. PMid:27692326.

Sangster N, Dobson RJ. Anthelmintic resistance. In: Lee DL, editor. The Biology of Nematodes. 1st ed. London: Taylor and Francis; 2002.p. 351-567. http://dx.doi.org/10.1201/b12614-23.

Santos JML, Monteiro JP, Ribeiro WLC, Macedo ITF, Araújo-Filho JV, Andre WPP, et al. High levels of benzimidazole resistance and $\beta$ - tubulin isotype 1 SNP F167Y in Haemonchus contortus populations from Ceará State, Brazil. Small Rumin Res 2017 ; $146: 48-52$. http://dx.doi.org/10.1016/j.smallrumres.2016.11.023.

Santos JML, Monteiro JP, Ribeiro WL, Macedo ITF, Camurça-Vasconcelos ALF, Vieira LS, et al. Identification and quantification of benzimidazole resistance polymorphisms in Haemonchus contortus isolated in Northeastern Brazil. Vet Parasitol 2014; 199(3-4): 160-164. http://dx.doi.org/10.1016/j.vetpar.2013.11.006. PMid:24295955.

Santos JML, Vasconcelos JF, Frota GA, Freitas EP, Teixeira M, Vieira LS, et al. Quantitative molecular diagnosis of levamisole resistance in populations of Haemonchus contortus. Exp Parasitol 2019; 205: 107734. http://dx.doi.org/10.1016/j.exppara.2019.107734. PMid:31394093.

Sarai R, Kopp S, Coleman G, Kotze AC. Acetylcholine receptor subunit and P-glycoprotein transcription patterns in levamisolesusceptible and -resistant Haemonchus contortus. Int J Parasitol Drugs Drug Resist 2013; 3: 51-58. http://dx.doi.org/10.1016/j. ijpddr.2013.01.002. PMid:24533293.

Sarai RS, Kopp SR, Coleman GT, Kotze AC. Drug-efflux and target-site gene expression patterns in Haemonchus contortus larvae able to survive increasing concentrations of levamisole in vitro. Int J Parasitol Drugs Drug Resist 2014; 4(2): 77-84. http://dx.doi. org/10.1016/j.ijpddr.2014.02.001. PMid:25057457.

Silvestre A, Cabaret J. Mutation in position 167 of isotype $1 \beta$-tubulin gene of Trichostrongylid nematodes: role in benzimidazole resistance? Mol Biochem Parasitol 2002; 120(2): 297-300. http://dx.doi.org/10.1016/S0166-6851(01)00455-8. PMid:11897135.

Ueno H, Gonçalves PC. Manual para diagnóstico das helmintoses de ruminantes. Tokyo: Japan International Cooperation Agency; 1998.

Van den Brom R, Moll L, Kappert C, Vellema P. Haemonchus contortus resistance to monepantel in sheep. Vet Parasitol 2015; 209(3-4): 278-280. http://dx.doi.org/10.1016/j.vetpar.2015.02.026. PMid:25770852.

Vieira LS, Berne MEA, Cavalcante ACR. Redução do número de ovos por grama de fezes (OPG) em caprinos medicados com antihelmínticos. Sobral: EMBRAPA-CNPC; 1989. (Boletim de Pesquisa e Desenvolvimento). 